\title{
Treatment of grain with organic acids at 2 different dietary phosphorus levels modulates ruminal microbial community structure and fermentation patterns in vitro
}

\author{
H. Harder, ${ }^{*} \dagger$ A. Khol-Parisini, ${ }^{\dagger} \dagger$ B. U. Metzler-Zebeli,†‡ F. Klevenhusen, ${ }^{\star} \dagger$ and Q. Zebeli ${ }^{*}{ }^{1}$ \\ ${ }^{*}$ Institute of Animal Nutrition and Functional Plant Compounds, \\ †Research Cluster Animal Gut Health, and \\ łUniversity Clinic for Swine, Department for Farm Animals and Veterinary Public Health, University of Veterinary Medicine Vienna, \\ 1210 Vienna, Austria
}

\section{ABSTRACT}

Recent data indicate positive effects of treating grain with citric (CAc) or lactic acid (LAc) on the hydrolysis of phytate phosphorus $(\mathrm{P})$ and fermentation products of the grain. This study used a semicontinuous rumen simulation technique to evaluate the effects of processing of barley with $50.25 \mathrm{~g} / \mathrm{L}$ (wt/vol) CAc or $76.25 \mathrm{~g} / \mathrm{L}$ LAc on microbial composition, metabolic fermentation profile, and nutrient degradation at low or high dietary $\mathrm{P}$ supply. The low $\mathrm{P}$ diet $[3.1 \mathrm{~g}$ of $\mathrm{P}$ per $\mathrm{kg}$ of dry matter (DM) of dietary P sources only] was not supplemented with inorganic $\mathrm{P}$, whereas the high $\mathrm{P}$ diet was supplemented with $0.5 \mathrm{~g}$ of inorganic $\mathrm{P}$ per $\mathrm{kg}$ of $\mathrm{DM}$ through mineral premix and $870 \mathrm{mg}$ of inorganic $\mathrm{P} / \mathrm{d}$ per incubation fermenter via artificial saliva. Target microbes were determined using quantitative PCR. Data showed depression of total bacteria but not of total protozoa or short-chain fatty acid (SCFA) concentration with the low $\mathrm{P}$ diet. In addition, the low $\mathrm{P}$ diet lowered the relative abundance of Ruminococcus albus and decreased neutral detergent fiber (NDF) degradation and acetate proportion, but increased the abundance of several predominantly noncellulolytic bacterial species and anaerobic fungi. Treatment of grain with LAc increased the abundance of total bacteria in the low P diet only, and this effect was associated with a greater concentration of SCFA in the ruminal fluid. Interestingly, in the low $\mathrm{P}$ diet, CAc treatment of barley increased the most prevalent bacterial group, the genus Prevotella, in ruminal fluid and increased NDF degradation to the same extent as did inorganic $\mathrm{P}$ supplementation in the high $\mathrm{P}$ diet. Treatment with either CAc or LAc lowered the

Received June 6, 2015

Accepted July 5, 2015.

${ }^{1}$ Corresponding author: qendrim.zebeli@vetmeduni.ac.at abundance of Megasphaera elsdenii but only in the low $\mathrm{P}$ diet. On the other hand, CAc treatment increased the proportion of acetate in the low $\mathrm{P}$ diet, whereas LAc treatment decreased this variable at both dietary $\mathrm{P}$ levels. The propionate proportion was significantly increased by LAc at both $\mathrm{P}$ levels, whereas butyrate increased only with the low $\mathrm{P}$ diet. Treatments with CAc or LAc reduced the degradation of $\mathrm{CP}$ and ammonia concentration compared with the control diet at both $\mathrm{P}$ levels. In conclusion, the beneficial effects of CAc and LAc treatment on specific ruminal microbes, fermentation profile, and fiber degradation in the low $\mathrm{P}$ diet suggest the potential for the treatment to compensate for the lack of inorganic $\mathrm{P}$ supplementation in vitro. Further research is warranted to determine the extent to which the treatment can alleviate the shortage of inorganic P supplementation under in vivo conditions.

Key words: lactic acid, citric acid, phosphorus, rumen microbiota, Rusitec

\section{INTRODUCTION}

Cereal grains are important ingredients in the diet of high-producing ruminants. Besides supplying energy for rumen microbes and the host, grains are important sources of minerals, especially of phosphorus (P). Phosphorus nutrition has received renewed interest due to its potential environmental effects and the limitations of the global raw phosphate stores (Kincaid and Rodehutscord, 2005). From a nutritional point of view, a major challenge is to meet the requirements of the animal while minimizing $\mathrm{P}$ excretion to the environment (Humer and Zebeli, 2015). On the other hand, in vitro ruminant studies have shown that low $\mathrm{P}$ supply decreases microbial protein synthesis, cellulose degradation, and the formation of short-chain fatty acids (SCFA; Komisarczuk et al., 1987a,b), indicating decreased ruminal microbial activity and fermentation efficiency due to insufficient $\mathrm{P}$ supply. 
In cereal grains and legumes, 60 to $80 \%$ of $\mathrm{P}$ is stored as phytic acid (myo-inositol 6 hexakisphosphate, $\mathbf{I n s}_{\mathbf{6}}$; Reddy et al., 1982; Viveros et al., 2000), potentially reducing its ruminal solubility and consequently the availability for ruminants (Field, 1981). In contrast to monogastric animals, the $\mathrm{InsP}_{6}$ is completely available for ruminants, due to a high phytase activity of ruminal microbes (Clark et al., 1986; Morse et al., 1992; Feng et al., 2013). However, other studies have shown that the rumen degradation of InsP $_{6}$ may be incomplete (Park et al., 2000; Kincaid et al., 2005; Jarrett et al., 2014), whereby various factors such as feed physical properties, short ruminal retention time (Kincaid et al., 2005; Jarrett et al., 2014), and processing of feedstuffs with formaldehyde or heat (Konishi et al., 1999; Park et al., 2000; Bravo et al., 2000) seem to play a role. Newer research data indicate that ruminal degradability of $\mathrm{InsP}_{6}$ is increased by supplementing exogenous phytase to dairy cow diets, resulting in a higher $\mathrm{P}$ availability for ruminal microbiota and the host (Kincaid et al., 2005; Brask-Pedersen et al., 2013; Jarrett et al., 2014). These findings indicate that ruminants can still benefit from native plant $\mathrm{InsP}_{6}$ hydrolysis triggered by exogenous phytase supplementation, thereby likely alleviating their dependency on inorganic P supplementation.

Haraldsson et al. (2004) showed that treating cereals with low concentrations of lactic acid (LAc), a mild organic acid widely used in food technology, promoted the hydrolysis of $\operatorname{InsP}_{6}$. More recently, Metzler-Zebeli et al. (2014) reported a linear increase in the hydrolysis of $\mathrm{InsP}_{6}$ by treating grain with graded levels of LAc from 7.63 to $76.25 \mathrm{~g} / \mathrm{L} \mathrm{LAc}$. In addition, we have observed that processing grain with $76.25 \mathrm{~g} / \mathrm{L}$ LAc results in an increase of slowly digestible starch (Deckardt et al., 2014, 2015). Our more recent studies have shown that treatment with citric acid (CAc), another organic acid frequently used in the feed and food industries, increased mineral solubility and concentration of soluble fiber fractions in barley (Harder et al., 2015a,b), with potential benefits for gastrointestinal microbial activity.

Because of these changes in $\mathrm{InsP}_{6}$ hydrolysis and fermentation products in grains, we hypothesized that treatment with CAc or LAc may modulate the abundance of key ruminal microbes, their fermentation patterns, and nutrient degradation, thus compensating potential impairment of rumen microbial activity due to the lack of inorganic $\mathrm{P}$ supplementation. Therefore, this study used a targeted quantitative PCR (qPCR) approach coupled with the fermentation profile to investigate the effects of treatment of grain with CAc and LAc at different dietary $\mathrm{P}$ supplies on changes in the abundance of fibrolytic and amylolytic microbiota and their patterns of fermentation in a standardized semicontinuous rumen simulation technique (Rusitec), which has been used in similar studies (Deckardt et al., 2015).

\section{MATERIALS AND METHODS}

\section{Grain Processing}

Samples of a 2-row summer barley cultivar 'Espinosa' (Saatzucht Edelhof, Austria) were ground with a knife mill (Grindomix, GM200, Retsch, Haan, Germany) for $17 \mathrm{~s}$ at 5,000 rpm. Subsequently, these barley grain samples were soaked in distilled water as control (CON) in a ratio of 1:1.2 (wt/vol) or in $76.25 \mathrm{~g} / \mathrm{L}$ LAc (DL-lactate, $80 \%$ wt/wt, Brenntag CEE GmbH, Vienna, Austria) or $50.25 \mathrm{~g} / \mathrm{L}$ CAc (99.5\%, Solan Kraftfutterwerk Schmalwieser GmbH, Bachmanning, Austria) for $24 \mathrm{~h}$ at $22^{\circ} \mathrm{C}$. The soaking procedure was the same as used in our previous work (Harder et al., 2015a,b). We used concentrations of $50.25 \mathrm{~g} / \mathrm{L}$ CAc and $76.25 \mathrm{~g} / \mathrm{L}$ LAc because these concentrations showed the best results both in terms of $\mathrm{InsP}_{6}$ hydrolysis (MetzlerZebeli et al., 2014) and modification of other chemical components of barley (Harder et al., 2015a,b). On average, each gram of barley grain absorbed $0.75 \mathrm{~mL}$ of fluid. Subsequently, the treated barley samples were spread onto petri dishes $(94 \times 16 \mathrm{~mm})$ and air-dried at $22^{\circ} \mathrm{C}$ for $72 \mathrm{~h}$.

\section{Experimental Diets}

The basal diet consisted of meadow hay (second cut), solvent-extracted soybean meal, barley grains (i.e., CON, CAc, or LAc), and 1 of 2 vitamin-mineral premixes (Biomin M16; Biomin GmbH, Herzogenburg, Austria) for dairy cows, one containing no inorganic $\mathrm{P}$ source and the other containing inorganic $\mathrm{P}$ sources (Table 1). Hay was ground to pass a $2-\mathrm{mm}$ sieve (Pulverisette Type 14702, Fritsch GmbH, Idar-Oberstein, Germany) and subsequently mixed with other ingredients, resulting in 3 different diets (i.e., CON, CAc, and LAc) for the Rusitec experiment (Table 1).

\section{Rumen Simulation Technique}

The Rusitec system (Czerkawski and Breckenridge, 1977), consisting of 12 incubation units, was used as described in previous studies (Deckardt et al., 2015). A total amount of $349.92 \mathrm{~mL}$ of buffer solution per day (flow rate: $0.243 \mathrm{~mL} / \mathrm{min}$ ) were infused continuously in each fermenter using a 12-channel peristaltic pump (IPC-N 12/ISM 937, IDEX Health \& Science GmbH, Wertheim, Germany). Two buffer solutions were prepared to investigate our hypotheses (Table 2). The artificial saliva was prepared according to McDougall 
Table 1. Ingredients and nutrient composition ( $\mathrm{g} / \mathrm{kg}$ of DM unless otherwise noted) of the basal $\operatorname{diets}^{1}$

\begin{tabular}{lrrr}
\hline & & \multicolumn{2}{c}{ Treatment } \\
\cline { 3 - 4 } Item & CON & CAc & LAc \\
\hline Diet ingredient & 485 & 485 & 485 \\
Meadow hay & 400 & 400 & 400 \\
Barley grain (untreated or treated with CAc or LAc) & 100 & 100 & 100 \\
Soybean meal & 15 & 15 & 15 \\
Vitamin-mineral mix (with or without phosphorus) & & & \\
Chemical composition of diet & 887 & 887 & 892 \\
DM (g/kg) & 942 & 943 & 943 \\
OM & 142 & 137 & 136 \\
NDF & 361 & 362 & 357 \\
\hline
\end{tabular}

${ }^{1} \mathrm{CON}=$ diet with untreated barley grain 'Espinosa' serving as control; CAc $=$ diet with 'Espinosa' treated with $50.25 \mathrm{~g} / \mathrm{L}$ citric acid; LAc = diet with 'Espinosa' treated with $76.25 \mathrm{~g} / \mathrm{L}$ lactic acid.

${ }^{2}$ For the diet containing inorganic phosphorus, the vitamin-mineral mix contained (per g of DM): Ca, $192 \mathrm{mg}$; P, 40 mg; Na, 111 mg; Mg, 40 mg; Se, 0.04 mg; vitamin A, $240 \mu \mathrm{g}$; vitamin $\mathrm{D}_{3}, 1.8 \mu \mathrm{g}$; vitamin E, $2 \mathrm{~g}$. For the diet containing no inorganic phosphorus, the vitamin-mineral mix contained (per g of DM): Ca, $192 \mathrm{mg}$; $\mathrm{Na}$, $111 \mathrm{mg} ; \mathrm{Mg}$, $40 \mathrm{mg}$; Se, $0.04 \mathrm{mg}$; vitamin A, $240 \mu \mathrm{g}$; vitamin $\mathrm{D}_{3}, 1.8 \mu \mathrm{g}$; vitamin E, $2 \mathrm{~g}$.

(1948), and for the P-deficient treatments, a buffer was prepared without inorganic P but with a similar estimated osmolarity as the McDougall buffer (343 vs. $346 \mathrm{mOsm})$.

To prepare the inocula for the experiment, ruminal fluid and solid digesta were obtained separately for each run from 3 nonlactating, rumen-cannulated Holstein cows, which had been fed hay $(8.4 \% \mathrm{CP}$ and $54.8 \%$ $\mathrm{NDF}$ on a DM basis) ad libitum and a daily allowance of $0.5 \mathrm{~kg}$ of concentrate $(15.1 \% \mathrm{CP}$ and $14.9 \% \mathrm{NDF}$ on DM basis) for $28 \mathrm{~d}$ before beginning the Rusitec trial. Cows were kept according to the Austrian guidelines for animal welfare (Federal Ministry of Health, 2004). Inoculation of the system was done as described previously (Deckardt et al., 2015).

\section{Experimental Procedure, Sampling, and Analyses}

The experiment was conducted in 3 identical experimental runs. Each run lasted $10 \mathrm{~d}$ : an adaptation period of $5 \mathrm{~d}$, used for equilibration of the system, followed by $5 \mathrm{~d}$ for samplings (Deckardt et al., 2015). The ex-

Table 2. Buffer solutions with or without inorganic phosphorus and used in the Rusitec experiment (modified after McDougall's artificial saliva composition formula)

\begin{tabular}{llcc}
\hline Variable & Composition & With $\mathrm{P}^{1}$ & Without P \\
\hline Solution A & $\mathrm{NaHCO}_{3}(\mathrm{~g})$ & 49.0 & 65.0 \\
& $\mathrm{Na}_{2} \mathrm{HPO}_{4} \cdot 2 \mathrm{H}_{2} \mathrm{O}(\mathrm{g})$ & 23.38 & - \\
\multirow{3}{*}{ Solution B } & $\mathrm{Distilled} \mathrm{H}_{2} \mathrm{O}(\mathrm{mL})$ & 4,950 & 4,950 \\
& $\mathrm{NaCl}(\mathrm{g} / \mathrm{L})$ & 47 & 47 \\
& $\mathrm{KCl}(\mathrm{g} / \mathrm{L})$ & 57 & 57 \\
& $\mathrm{CaCl} \cdot 2 \mathrm{H}_{2} \mathrm{O}(\mathrm{g} / \mathrm{L})$ & 5.3 & 5.3 \\
& $\mathrm{MgCl}_{2} \cdot 6 \mathrm{H}_{2} \mathrm{O}(\mathrm{g} / \mathrm{L})$ & 12.8 & 12.8 \\
\hline
\end{tabular}

${ }^{1}$ The buffer with $\mathrm{P}$ delivered $870 \mathrm{mg}$ of $\mathrm{P}$ per fermentation vessel per day. periment was designed as a randomized $3 \times 2$ factorial design with barley treatment (i.e., CON, CAc, or LAc diet) and inorganic $\mathrm{P}$ supplementation (supplemented or not) as main factors, resulting in 6 diets tested with 2 replicates in each run, for 6 independent measurements per treatment.

The diets without inorganic $\mathrm{P}$ supplementation contained on average $3.1 \mathrm{~g}$ of $\mathrm{P} / \mathrm{kg}$ of $\mathrm{DM}$, from only dietary sources; the buffer was free of inorganic P (Table 2 ), and these diets were considered the low $\mathrm{P}$ diets. The diet with inorganic $\mathrm{P}$ supplementation contained $3.1 \mathrm{~g}$ of $\mathrm{P} / \mathrm{kg}$ of $\mathrm{DM}$ from dietary sources plus $0.5 \mathrm{~g}$ of $\mathrm{P} /$ $\mathrm{kg}$ of $\mathrm{DM}$ as $\mathrm{Ca}\left(\mathrm{H}_{2} \mathrm{PO}_{4}\right)_{2}$ through the mineral-vitamin premix, plus $870 \mathrm{mg}$ of $\mathrm{P}$ per fermentation vessel/d as $\mathrm{Na}_{2} \mathrm{HPO}_{4} \cdot 2 \mathrm{H}_{2} \mathrm{O}$ via buffer (Table 2 ). Treatments with inorganic $\mathrm{P}$ supplementation were considered high $\mathrm{P}$ diets. Daily, fluid samples of each fermenter were collected $1 \mathrm{~h}$ before the feeding procedure to measure $\mathrm{pH}$, redox potential, and ammonia concentration, using a syringe inserted through a 3-way valve. For these measurements, a digital pH meter (S400 Seven Excellence, Mettler-Toledo, Greifensee, Switzerland) was used, with calibration buffers of $\mathrm{pH} 4.0$ and $\mathrm{pH}$ 7.0. Fermentation gases were collected on each sampling day over $24 \mathrm{~h}$ in gas-tight aluminum bags (Tecobag 8 1, Tesseraux Spezialverpackungen $\mathrm{GmbH}$, Bürstadt, Germany) and $\mathrm{CH}_{4}$ and $\mathrm{CO}_{2}$ concentrations were determined (ATEX Biogas Monitor Check BM 2000, Ansyco, Karlsruhe, Germany). The total gas amount was quantified using the water displacement technique (Deckardt et al., 2015).

On each sampling day, at $0,1,2,4$, and $6 \mathrm{~h}$ after feeding, fluid samples of each fermenter $(1.8 \mathrm{~mL})$ were taken and frozen at $-20^{\circ} \mathrm{C}$ before being analyzed for the concentration of SCFA. For lactate measurements, $2 \mathrm{~mL}$ of fermenter fluid was frozen at $-20^{\circ} \mathrm{C}$ and later 
analyzed enzymatically (D-/L-Lactic Acid Assay Kit, Megazyme International Ireland Ltd., Co. Wicklow, Ireland).

Nutrient analysis included determinations of DM, ash, CP, and NDF. All chemical analyses were done in duplicate according to the German Handbook of Agricultural Experimental and Analytical Methods (VDLUFA, 2006). Total DM was determined by oven drying at $105^{\circ} \mathrm{C}$ overnight. Samples were analyzed for ash by combustion overnight at $580^{\circ} \mathrm{C}$. The NDF was analyzed based on Van Soest et al. (1991; Fiber Therm FT 12 Fa. C. Gerhardt GmbH \& Co. KG, Königswinter, Germany) using heat-stable $\alpha$-amylase (Termamyl $120 \mathrm{~L}$, 120 KNU-T/g, Novozymes A/S, Bagsvaerd, Denmark) and expressed exclusive of residual ash. Crude protein was analyzed by the Kjeldahl method $(\mathrm{CP}=\mathrm{N} \times 6.25)$. The $\mathrm{P}$ content was determined photometrically using the vanado-molybdate method, which measures the color intensity at $436 \mathrm{~nm}$ after wet-ashing the lyophilized samples in $\mathrm{HNO}_{3}$ and $\mathrm{H}_{2} \mathrm{O}_{2}$ via microwave (MLSETHOS plus Terminal 320, Leutkirch, Germany).

\section{Total DNA Extraction and qPCR Analysis}

Original ruminal fluid of cows and fermenter fluid samples, collected at $6 \mathrm{~h}$ after incubation, was frozen at $-80^{\circ} \mathrm{C}$ for later microbial determination by quantitative PCR. Samples from the 5 sampling days were pooled per fermenter and used for total DNA extraction. Fluid samples were thawed on ice and thoroughly homogenized before taking a subsample of approximately $300 \mu \mathrm{L}$ for DNA extraction using the PowerSoil DNA isolation kit (MoBio Laboratories Inc., Carlsbad, CA). This kit uses a bead-beating step to dissociate microbes from feed particles and disrupt the microbial cells. A heating step of $70^{\circ} \mathrm{C}$ for 10 min was included after mixing samples with buffer $\mathrm{C} 1$ to ensure proper lysis of bacteria (Metzler-Zebeli et al., 2013). The concentration of DNA was quantified (Nanodrop-2000 spectrophotometer; NanoDrop Technologies, Wilmington, DE) and sample volumes were adjusted to achieve similar DNA concentrations across samples (Mullins et al., 2013).

Primer sets used for qPCR targeted the $16 \mathrm{~S}$ rRNA gene of eubacteria and archaea and the $18 \mathrm{~S}$ rRNA gene of protozoa, as described previously (Supplemental Table S1; http://dx.doi.org/10.3168/jds.2015-9913). We focused on well-studied microbial taxa, which should allow more inferences to be made about the metabolic consequences of changes in ruminal ecology, compared with assessing the whole microbiome, where many detected species are still entirely uncharacterized (Mullins et al., 2013). Their currently known specificities were checked in silico by BLAST search in GenBank (www.
ncbi.nlm.nih.gov/BLAST/). Primer sets to detect $B u$ tyrivibrio fibrisolvens, Ruminococcus flavefaciens, and Selenomonas ruminantium were not completely monospecific; therefore, the assemblage identified by these primer sets will be referred to as the B. fibrisolvens group, the $R$. flavefaciens group, and the S. ruminantium group, as also suggested by Mullins et al. (2013) and Mohammed et al. (2014). The qPCR analysis was performed using the Stratagene Mx3000P QPCR System (Agilent Technologies, Santa Clara, CA) using the Brilliant II SYBR Green QPCR Low ROX master mix kit (Agilent Technologies). Samples and standards were assayed in $25-\mu \mathrm{L}$ reaction mixtures containing $12.5 \mu \mathrm{L}$ of master mix, forward and reverse primers $(400 \mathrm{n} M)$, and $1 \mu \mathrm{L}$ of DNA template. The amplification program included an initial denaturation step at $95^{\circ} \mathrm{C}$ for 10 min, followed by 40 cycles of $95^{\circ} \mathrm{C}$ for $15 \mathrm{~s}$, optimal annealing temperature (Supplemental Table S1; http:// dx.doi.org/10.3168/jds.2015-9913) for $30 \mathrm{~s}$, and $72^{\circ} \mathrm{C}$ for $30 \mathrm{~s}$. Fluorescence was measured at the last step of each cycle. Melting curve analysis was performed to determine the specificity of the amplification. The dissociation of PCR products was monitored by slow heating with an increment of $0.1^{\circ} \mathrm{C} / \mathrm{s}$ from 55 to $95^{\circ} \mathrm{C}$, with fluorescence measurement at $0.1^{\circ} \mathrm{C}$ intervals. The PCR product length was additionally verified by horizontal gel electrophoresis. The $2 \%$ agarose gel contained $2 \mu \mathrm{L}$ of Midori Green Advanced DNA Stain (Biozym Scientific GmbH, Hessisch Oldendorf, Germany) for visualization of DNA bands under UV light. A 2-kb ladder (Quantitas DNA Marker, Biozym Scientific GmbH) was included on each gel for confirmation of the correct size of the amplified product. Samples, standards, and negative controls without template DNA were run in duplicate.

Standard curves for each bacterial group and species were generated using 10 -fold serial dilutions $\left(10^{7}\right.$ to $10^{3}$ molecules $/ \mu \mathrm{L}$ ) of the purified and quantified PCR products generated by qPCR using DNA from ruminal fluid of the present experiment and the corresponding primer sets (Metzler-Zebeli et al., 2013; Deckardt et al., 2015). For quantification of total eubacteria, total protozoa, and total methanogens, standard curves were constructed by using universal primers to amplify serial dilutions of purified PCR products from DNA of ruminal fluid (Metzler-Zebeli et al., 2013). Amplification efficiency $E$ was calculated according to the following equation: $E=-1+10^{-1 / \text { slope }}$ (Supplemental Table S1; http://dx.doi.org/10.3168/jds.2015-9913). Gene copy numbers of total bacteria and target bacterial groups were determined by relating the cycle quantification $\left(\mathbf{C}_{\mathbf{q}}\right)$ values to standard curves. The final copy numbers of total bacteria, total protozoa, total methanogens, and fungi were calculated by considering the copy number, 
dilution of the DNA extract, and the volume of sample subjected to DNA extraction, as previously described (Metzler-Zebeli et al., 2013). Abundances of the eubacterial groups, the archaeal methanogens, and the protozoal groups and species were expressed as proportion of the total eubacterial $16 \mathrm{~S}$ rRNA gene, the total archaeal $16 \mathrm{~S}$ rRNA gene, and the total protozoal 18S rRNA gene (relative quantification $=2^{- \text {(Cq-target }- \text { Cq-total bacteria) }}$; Deckardt et al., 2015), and the coverage of total bacteria by bacterial groups was expressed as percentage of total bacteria (Metzler-Zebeli et al., 2013).

\section{Microbial Fermentation and Nutrient Degradation}

The SCFA (acetic acid, propionic acid, isobutyric acid, $n$-butyric acid, isovaleric acid, $n$-valeric acid, and caproic acid) were determined by GC (GC model 8060 MS DPFC, no. 950713, Fisons, Rodano, Italy) in the supernatant fractions of the fermenter fluid samples obtained by centrifugation $(15,000 \times g$ for $20 \mathrm{~min}$ at $4^{\circ} \mathrm{C}$, Avanti 30, Beckmann, Krefeld, Germany). Sample preparation included mixing of $0.6 \mathrm{~mL}$ of the supernatant with $0.2 \mathrm{~mL}$ of deionized water, $0.2 \mathrm{~mL}$ of $1.8 \mathrm{M}$ hydrochloric acid, and $0.2 \mathrm{~mL}$ of the internal standard (4-methylvaleric acid) followed by a second centrifugation at $15,000 \times g$ for $20 \mathrm{~min}$ at $4^{\circ} \mathrm{C}$. Subsequently, the SCFA were analyzed in a GC fitted with a flame-ionization detector and a $30-\mathrm{m} \times 0.530-\mathrm{mm} \times 0.53-\mu \mathrm{m}$ capillary column (Trace TR Wax, Thermo Fisher Scientific, Waltham, MA). Helium was supplied as the carrier gas at a flow rate of $2 \mathrm{~mL} / \mathrm{min}$. Injection port and detector temperatures were $170^{\circ} \mathrm{C}$ and $190^{\circ} \mathrm{C}$, respectively. Data were handled using the Stratos Software (Stratos version 3.0, Polymer Laboratories, Church Stretton, UK).

Determination of nutrient degradation was performed as described earlier (Deckardt et al., 2015). In brief, the bags with the feed residues after $48 \mathrm{~h}$ of incubation were washed with cold water until the water became clear and were then stored at $-20^{\circ} \mathrm{C}$. Subsequently, the samples of the last $5 \mathrm{~d}$ were pooled, oven-dried at $50^{\circ} \mathrm{C}$ for $48 \mathrm{~h}$, ground to pass a sieve of $2 \mathrm{~mm}$ (Pulverisette Type 14702, Fritsch GmbH), and analyzed for their nutrient contents. Differences in the chemical composition of feed and feed residues were regarded as degraded nutrients.

\section{Statistical Analysis}

Data were analyzed for normality using the ShapiroWilk test. Analysis of variance was conducted with the Mixed procedure of SAS (9.2 version, SAS Institute Inc., Cary, NC) with treatments (barley treatment, $\mathrm{P}$ supplementation, and their 2-way interaction) as fixed effects and replicate within run as random effect.
Degrees of freedom were estimated with the KenwardRoger method. Data of SCFA and other fermentation variables, measured at different times on the same subject, were considered as repeated measures with an autoregressive variance-covariance method to model their time-dependency. Differences at $P \leq 0.05$ were declared significant, whereas a tendency was considered at the $0.05<P<0.10$ level. Multiple comparisons were done by Tukey's method. For illustration of microbial shifts related to grain treatment and $\mathrm{P}$ supply, a linear discriminant analysis was performed using JMP (version 10.0.0; SAS Institute Inc.). Total microbial abundances and target groups and species were used as covariates and diet as categorical variable, respectively.

\section{RESULTS}

\section{Abundance of Ruminal Microbes}

Results of the abundance of ruminal microbes as affected by dietary treatments are given in Table 3. Data showed an interaction $(P=0.005)$ between treatment of grain with organic acids and dietary $\mathrm{P}$ levels for the total bacterial $16 \mathrm{~S}$ rRNA gene copy number. The LAc treatment increased the total bacterial gene copy number at low $\mathrm{P}$ conditions but not at high $\mathrm{P}$ conditions. The coverage of total bacteria by the target bacterial groups and species showed a treatment effect $(P=$ 0.017 ), whereby the CAc treatment increased this variable under low $\mathrm{P}$ conditions compared with the $\mathrm{CON}$ $\operatorname{diet}(P=0.03)$. Inorganic $\mathrm{P}$ supplementation increased the coverage of total bacteria by the target bacterial groups and species in this study $(P<0.001$; Table 3$)$.

The CAc treatment increased the abundance of genus Prevotella at low $\mathrm{P}$ conditions $(P=0.015)$, which was generally the most prevalent genus in fermenter fluid. Inorganic P supplementation also increased the abundance of genus Prevotella. Selenomonas ruminantium was decreased when barley was treated with $\mathrm{CAc}$ at the high $\mathrm{P}$ level compared with other diets $(P=0.017)$. The treatment with CAc increased Clostridium cluster XIVa compared with the control at high $\mathrm{P}$ conditions, whereas this treatment did not affect Clostridium cluster XIVa at low $\mathrm{P}$ conditions. This finding resulted in an interaction $(P=0.025)$ between CAc treatment and dietary $\mathrm{P}$ level for this variable. Treatment with LAc enhanced Clostridium cluster XIVa at either P level in the diet.

The abundance of Butyrivibrio fibrisolvens decreased with $\mathrm{P}$ supplementation compared with the unsupplemented diet $(P=0.036)$. However, the abundance of the cellulolytic bacterium Ruminococcus albus was increased with $\mathrm{P}$ supplementation $(P=0.018)$. In contrast, amylolytic Ruminobacter amylophilus $(P=$ 
HARDER ET AL.

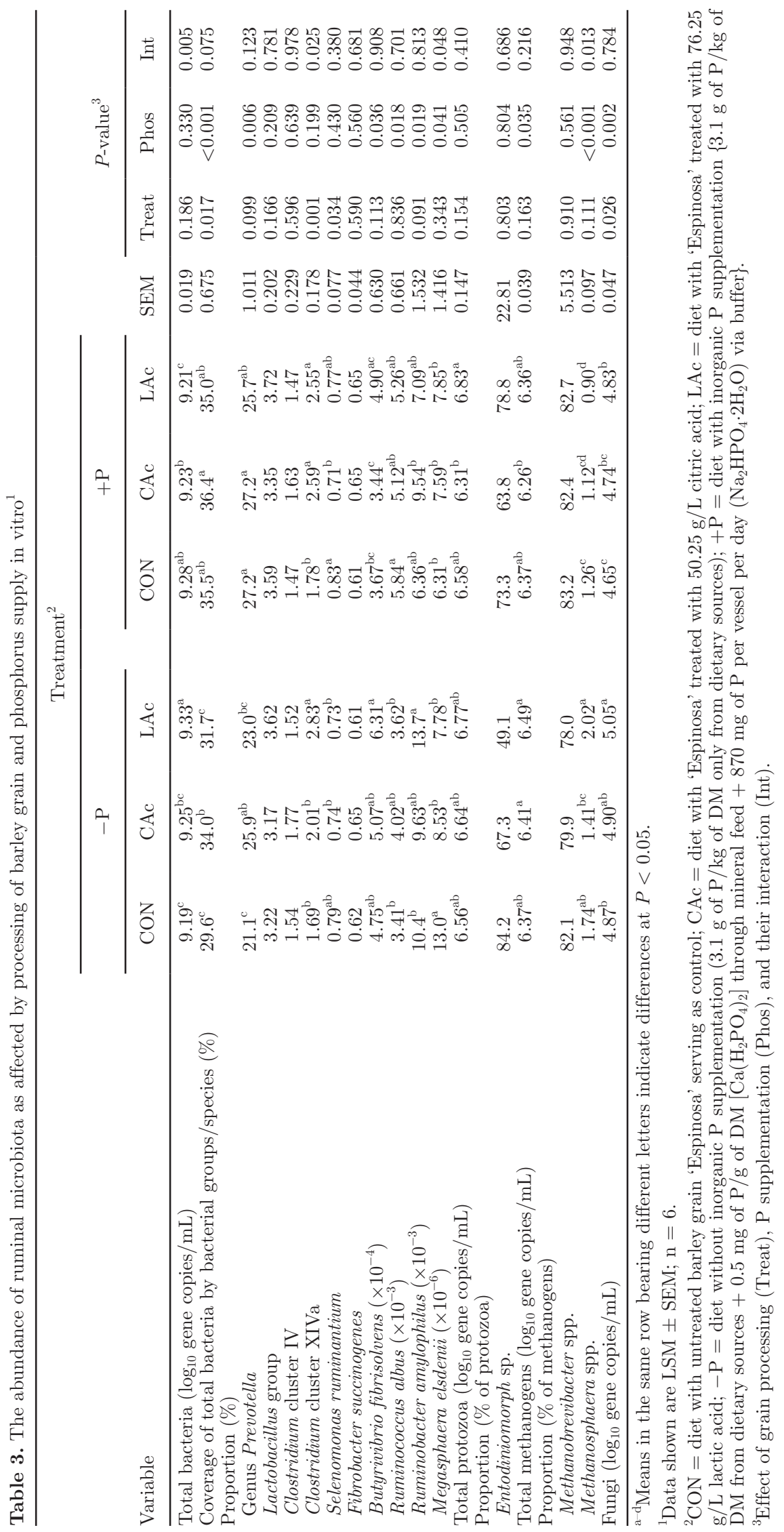


$0.019)$ and Megasphaera elsdenii $(P=0.041)$ both decreased with inorganic $\mathrm{P}$ supplementation. In addition, M. elsdenii was decreased by CAc and LAc treatment compared with the control but only in the unsupplemented diet, suggesting an interaction between the 2 dietary factors for this variable (Table 3 ).

Total protozoal gene copy numbers were unaffected by LAc and CAc treatment when the diet contained low $\mathrm{P}$ levels (Table 3 ). With $\mathrm{P}$ supplementation, in turn, protozoal gene copy numbers were 0.5 log units lower in fermenters receiving the CAc-treated barley compared with the LAc-treated barley; however, neither treatment differed from the CON treatment with $\mathrm{P}$ supplementation. Likewise, total methanogenic gene copy numbers were lower $(P<0.05)$ with $\mathrm{CAc}$ and inorganic $\mathrm{P}$ supplementation compared with LAc without $\mathrm{P}$ supplementation, whereas a low $\mathrm{P}$ level generally increased total methanogens $(P=0.035$; Table 3$)$ and, within the methanogens, the proportion of Methanosphaera spp. $(P<0.001)$ compared with the high $\mathrm{P}$ level (Table 3).

Moreover, we detected an interaction $(P=0.013)$ between $\mathrm{P}$ supplementation and grain processing with the highest relative abundance of Methanosphaera spp. observed for LAc and low P level and the lowest abundance for LAc treatment with $\mathrm{P}$ supplementation. For fungi, we observed an effect of barley treatment $(P=$ 0.026), whereby LAc increased the amount at both $\mathrm{P}$ levels $(P<0.05)$, and $\mathrm{P}$ supplementation lowered $(P=$ 0.002 ) the gene copy number of anaerobic fungi (Table $3)$.

Differences in microbial composition were also evaluated by linear discriminant analysis (Figure 1). This analysis revealed 5 major clusters respective to the treatment groups ( $\mathrm{P}$ supply and grain chemical treatment), which separated the responses obtained for the ruminal microbiota. Because the ellipses indicating the $95 \%$ CI of the means for CAc and LAc with $\mathrm{P}$ supplementation overlapped, suggesting no dissimilarity between them, they were considered a single cluster. However, the diets containing the grain treated with $\mathrm{CAc}$ and LAc without $\mathrm{P}$ supplementation differed from each other along the canonical axis 2 (Figure 1). In addition, in terms of the dissimilarity among the response clusters obtained, this analysis showed that multivariate means and the corresponding 95\% CI ellipses pertaining to $\mathrm{CON}$ without $\mathrm{P}$ supplementation and $\mathrm{CON}$ with $\mathrm{P}$ supplementation differed from each other, relative to canonical axes 1 and 2 . The analysis showed that the differences between the 2 control diets were much more substantive than those between diets with processed grains. The selection procedure of the best discriminant variables revealed that the abundance of Fibrobacter succinogenes and Clostridium cluster IV provided the best discrimination for the CON diet. Protozoa and genus Prevotella better discriminated for the diet treated with LAc without P, whereas fungi, $R$. amylophilus, and Entodinium spp. offered the best discrimination for the diet treated with CAc and without P supplementation. Further, the discriminant analysis indicated that the cluster of microbial variables including the Lactobacillus group, methanogens, R. albus, B. fibrisolvens, Clostridium cluster XIVa, and S. ruminantium best discriminated the treatments of CAc and LAc with $\mathrm{P}$ supplementation (Figure 1).

\section{Fermentation Parameters and Nutrient Degradation}

Table 4 shows the fermentation patterns as affected by dietary treatments. These data indicate that treatments of barley with $\mathrm{CAc}$ and LAc lowered the $\mathrm{NH}_{3}$ concentration in the fermenter fluid $(P<0.001)$. Methane formation was not affected by treatment, whereas $\mathrm{CO}_{2}$ tended to be increased $(P=0.068)$ by LAc compared with other diets. The $\mathrm{pH}$ of the fermenter fluid and the total gas amount were not affected by either organic acid treatment. However, supplementation with $\mathrm{P}$ slightly lowered $\mathrm{pH}$ values over the 24 -h incubation period compared with the treatments without $\mathrm{P}$ supplementation $(P<0.001)$. Regarding redox potential, we observed lower values in the low $\mathrm{P}$ diet than in the P-supplemented diet $(P=0.003)$. The different dietary $\mathrm{P}$ concentrations did not affect the $\mathrm{NH}_{3}$ concentration but total gas production was decreased $(P=0.021)$ with $\mathrm{P}$ supplementation. We detected no interaction between grain processing and $\mathrm{P}$ supplementation for these variables.

Although total SCFA formation was not affected by the grain processing method, data showed that the CAc treatment of barley increased this variable in the fermenter fluid compared with the CON and LAc diet at low $\mathrm{P}$ conditions but not at high $\mathrm{P}$ conditions (Table 4). This resulted in an interaction $(P=0.045)$ between the acid treatments and the $\mathrm{P}$ levels for this variable. Interestingly, grain processing increased SCFA concentration in the low $\mathrm{P}$ diet but had no effect on SCFA in the diet with inorganic P supply.

Regarding SCFA proportions, we observed an effect of chemical treatment of barley for all SCFA, although the effects of CAc and LAc were different for the individual SCFA. For example, compared with CON, the proportion of acetate was increased by $\mathrm{CAc}$ at low $\mathrm{P}$ conditions only $(P<0.05)$ but decreased with LAc treatment at both $\mathrm{P}$ levels compared with $\mathrm{CON}$ $(P<0.001)$. Data also showed that the proportion of propionate was significantly increased by LAc-treated barley grain compared with $\mathrm{CON}$ at both $\mathrm{P}$ levels $(P$ $<0.001$ ); however, CAc treatment increased propio- 
nate compared with CON only at high P. Interestingly, $\mathrm{P}$ supplementation increased acetate proportion $(P$ $=0.019)$ and decreased propionate proportion $(P=$ 0.051). Furthermore, LAc-treated barley grain significantly increased the proportion of butyrate compared with $\mathrm{CON}$ at low $\mathrm{P}$ conditions $(P<0.001)$, whereas LAc and CAc treatments decreased the proportion of valerate compared with $\mathrm{CON}$ at both $\mathrm{P}$ levels $(P<$ 0.001). The proportion of the branched-chain fatty acid isovalerate was decreased with LAc- and CAc-treated barley compared with CON barley at both $\mathrm{P}$ levels $(P$ $<0.001)$. The acetate:propionate ratio was significantly decreased with LAc treatment compared with the CON diet at both $\mathrm{P}$ levels $(P<0.001)$, but not with CAc treatment, which decreased this ratio compared with the CON treatment, but only with high $\mathrm{P}$ supply. Overall, the P-supplemented diets showed a greater acetate:propionate ratio than the unsupplemented diets $(P=0.013)$. We also observed that barley grain treated with LAc resulted in increased DL- $(P<0.05)$ and Llactate $(P<0.05)$ concentrations compared with $\mathrm{CON}$, whereas neither CAc nor $\mathrm{P}$ supplementation affected lactate concentration (Table 4).

Table 5 shows data of the apparent disappearance of DM, OM, NDF, and CP. Barley treatment and inorganic $\mathrm{P}$ supplementation did not affect overall DM and $\mathrm{OM}$ degradation. The only difference was that CAc treatment of barley slightly lowered both variables at high $\mathrm{P}$ levels, resulting in an interaction between the 2 factors. Data showed that the low $\mathrm{P}$ diet resulted in lowered NDF degradation, but CAc treatment of barley enhanced this variable $(P<0.001)$. Overall, treatment with organic acids enhanced NDF degradation $(P<$ 0.001). Interestingly, CAc treatment further enhanced degradation of NDF in the P-supplemented diet $(P<$ 0.05). Degradation of CP was not affected by P supplementation but was decreased by chemical treatment of barley at high and low P levels.

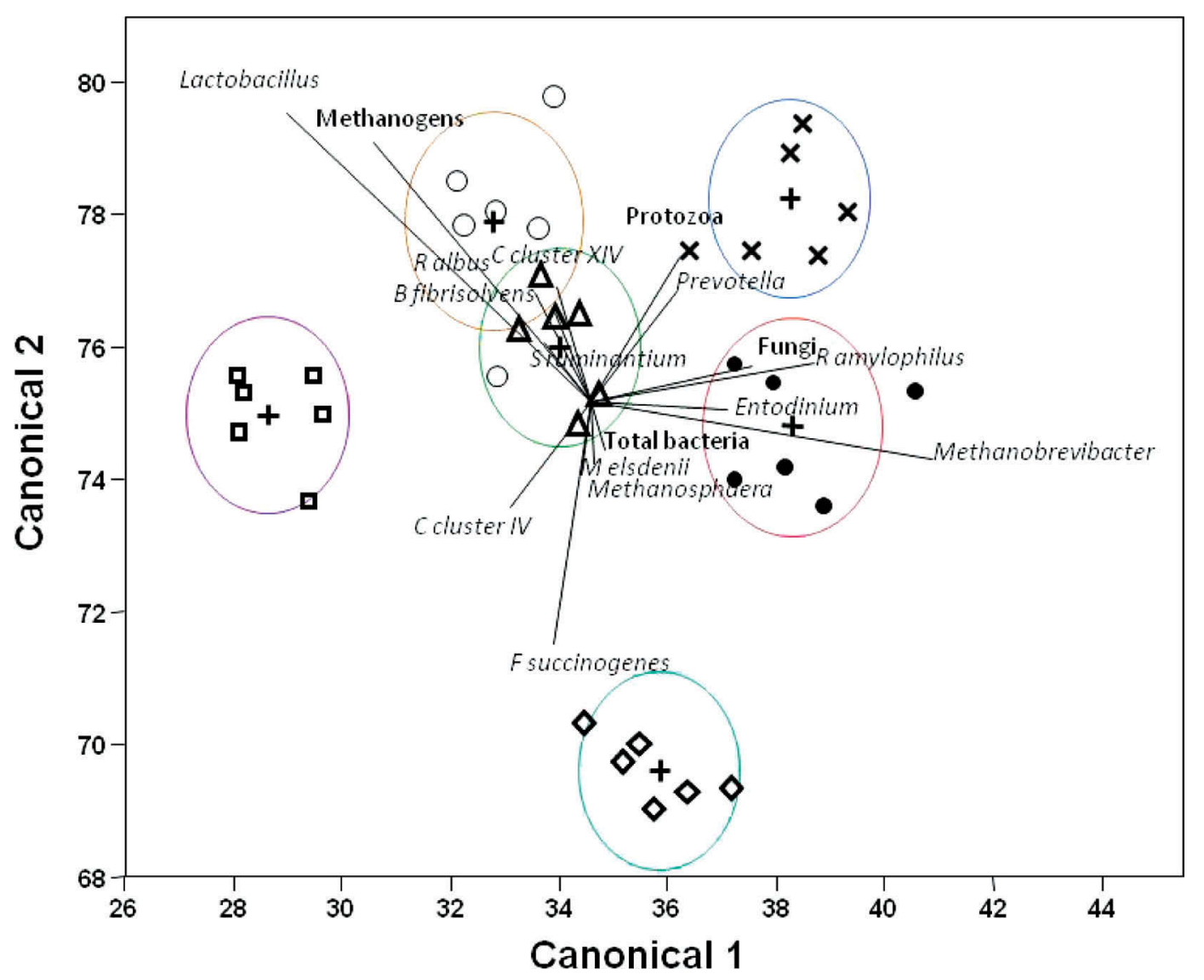

Figure 1. Linear discriminant analysis with the first 2 principal components of the bacterial, protozoal, archaeal and fungal populations for control diet without $(\diamond)$ or with $(\square)$ phosphorus supplementation, diet treated with citric acid without $(\bullet)$ or with $(\Delta)$ phosphorus supplementation, and diets treated with lactic acid without $(x)$ or with $(O)$ phosphorus supplementation; $\mathrm{n}=6$ per treatment. The plus sign $(+)$ indicates the multivariate mean of each independent variable (i.e., treatments), and the size of the ellipse indicates the $95 \%$ confidence limits of the mean. The distance between the treatments in the canonical axis 1 and 2 reflects their dissimilarity. The straight lines are indicative of dependent variables (microbiota) included in the analysis, and their length and angles between them are function of the relative effects of independent variables. Color version available online. 


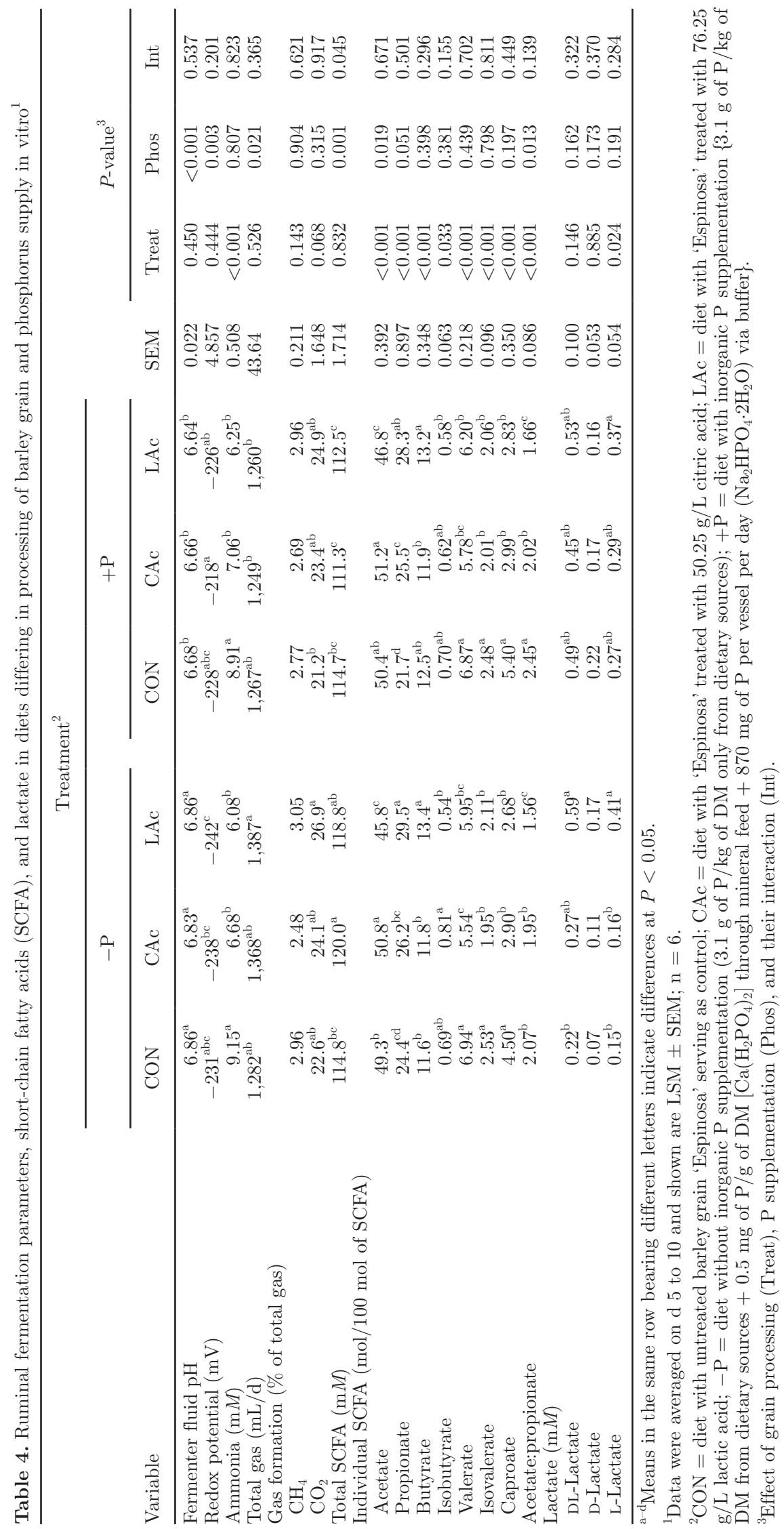


Table 5. Nutrient disappearance of diets differing in the processing of barley grain and phosphorus (P) supply in vitro ${ }^{1}$

\begin{tabular}{|c|c|c|c|c|c|c|c|c|c|c|}
\hline \multirow{2}{*}{ Variable (\%) } & \multicolumn{6}{|c|}{ Treatment $^{2}$} & \multirow{2}{*}{ SEM } & \multirow{2}{*}{\multicolumn{3}{|c|}{$P$-value ${ }^{3}$}} \\
\hline & \multicolumn{3}{|c|}{$-\mathrm{P}$} & \multicolumn{3}{|c|}{$+\mathrm{P}$} & & & & \\
\hline$\overline{\mathrm{DM}}$ & $65.0^{\mathrm{ab}}$ & $65.5^{\mathrm{a}}$ & $65.0^{\mathrm{b}}$ & $65.0^{\mathrm{ab}}$ & $64.5^{\mathrm{b}}$ & $65.5^{\mathrm{a}}$ & 0.25 & 0.884 & 0.218 & 0.029 \\
\hline $\mathrm{OM}$ & $64.1^{\mathrm{ab}}$ & $64.5^{\mathrm{a}}$ & $64.0^{\mathrm{b}}$ & $64.1^{\mathrm{ab}}$ & $63.5^{\mathrm{b}}$ & $64.3^{\mathrm{a}}$ & 0.26 & 0.823 & 0.265 & 0.028 \\
\hline $\mathrm{NDF}$ & $32.1^{\mathrm{c}}$ & $35.5^{\mathrm{ab}}$ & $32.5^{\mathrm{c}}$ & $34.6^{\mathrm{b}}$ & $36.1^{\mathrm{a}}$ & $35.1^{\mathrm{ab}}$ & 0.44 & 0.001 & 0.001 & 0.052 \\
\hline
\end{tabular}

${ }^{\mathrm{a}-\mathrm{c}}$ Means in the same row bearing different letters indicate differences at $P<0.05$.

${ }^{1}$ Data were averaged on $\mathrm{d} 5$ to 10 and shown are LSM \pm SEM; $\mathrm{n}=6$.

${ }^{2} \mathrm{CON}=$ diet with untreated barley grain 'Espinosa' serving as control; CAc $=$ diet with 'Espinosa' treated with $50.25 \mathrm{~g} / \mathrm{L}$ citric acid; LAc $=$ diet with 'Espinosa' treated with $76.25 \mathrm{~g} / \mathrm{L}$ lactic acid; $-\mathrm{P}=$ diet without inorganic $\mathrm{P}$ supplementation $(3.1 \mathrm{~g}$ of $\mathrm{P} / \mathrm{kg}$ of $\mathrm{DM}$ only from dietary sources $) ;+\mathrm{P}=$ diet with inorganic $\mathrm{P}$ supplementation $\left\{3.1 \mathrm{~g}\right.$ of $\mathrm{P} / \mathrm{kg}$ of $\mathrm{DM}$ from dietary sources $+0.5 \mathrm{mg}$ of $\mathrm{P} / \mathrm{g}$ of $\mathrm{DM}\left[\mathrm{Ca}\left(\mathrm{H}_{2} \mathrm{PO}\right)_{2}\right]$ through mineral feed $+870 \mathrm{mg}$ of $\mathrm{P}$ per vessel per day $\left(\mathrm{Na}_{2} \mathrm{HPO}_{4} \cdot 2 \mathrm{H}_{2} \mathrm{O}\right)$ via buffer $\}$.

${ }^{3}$ Effect of grain processing (Treat), $\mathrm{P}$ supplementation (Phos), and their interaction (Int).

\section{DISCUSSION}

We recently showed that treating barley grain with organic acids modified the nutrient composition and enhanced the hydrolysis of $\operatorname{InsP}_{6}$ (Deckardt et al., 2014; Metzler-Zebeli et al., 2014; Harder et al., 2015a). This study aimed to evaluate the effects of barley grain treated with CAc and LAc on the abundance of welldescribed ruminal microbial populations, their microbial fermentation patterns, and nutrient degradation in vitro. We hypothesized that the effects of treatment with CAc and LAc would be more pronounced without inorganic $\mathrm{P}$ supplementation. The low dietary $\mathrm{P}$ supply in this study consisted of $3.1 \mathrm{~g}$ of $\mathrm{P} / \mathrm{kg}$ of $\mathrm{DM}$ solely of dietary organic $\mathrm{P}$ sources, being slightly below the current $\mathrm{P}$ recommendations for dairy cattle (3.2 to 3.8 $\mathrm{g}$ of $\mathrm{P} / \mathrm{kg}$ of DM; NRC, 2001) and marginal in meeting maximal requirements of ruminal microbes $(4 \mathrm{~g}$ of $\mathrm{P} /$ $\mathrm{kg}$ of digestible OM; Durand and Kawashima, 1980). Phosphorus is an essential nutrient for rumen microbes, which have specific $\mathrm{P}$ requirements besides those of the host animal (Preston and Pfander, 1964; Durand and Komisarczuk, 1988; Lengeler et al., 1999).

As expected, we observed a significantly lower abundance of total bacteria and changes in bacterial composition, as indicated by the reduced coverage of total bacteria and depressed NDF degradation, with the low $\mathrm{P}$ diet. An important finding of this study was that grain processing with LAc and CAc increased the abundance of total bacteria and the abundance of target bacterial taxa in the low $\mathrm{P}$ diet but not in the high $\mathrm{P}$ diet, as suggested by the increased coverage of total bacteria by the current primers. Moreover, the relative proportion of the genus Prevotella decreased in response to the low $\mathrm{P}$ diet. As some members of this versatile genus hydrolyze starch and hemicellulose and secrete endoglucanases (Matsui et al., 2000), it may be feasible that mostly fibrolytic members were affected. Generally, low ruminal $\mathrm{P}$ availability is reported to reduce the abundance and metabolic activity of cellulolytic and hemicellulolytic bacteria, whereas amylolytic bacteria are less sensitive to low P (Durand and Komisarczuk, 1988). Accordingly, the cellulolytic bacterium R. albus was reduced by the low $\mathrm{P}$ diet. The key cellulolytic bacterium $F$. succinogenes is also reported to be sensitive to low ruminal $\mathrm{P}$ availability (Komisarczuk et al., 1988). However, it was not affected in the present study. Generally, gram-positive fibrolytic bacteria (e.g., $R$. albus) seem to have a 3 - to 5 -fold higher $\mathrm{P}$ demand than gram-negative fiber degraders (e.g., F. succinogenes) (Fonty et al., 1988). Hence, the $\mathrm{P}$ availability in the low $\mathrm{P}$ diet was likely sufficient to meet the $\mathrm{P}$ demand of $F$. succinogenes under present in vitro conditions.

The CAc treatment of barley combined with the high $\mathrm{P}$ diet improved NDF degradation. Improvement in in situ NDF degradation due to treatment with CAc has been reported previously for steers (Wang et al., 2009). Those authors observed improved ruminal fibrolytic bacterial activity resulting in an increased ruminal acetate concentration, similar to the present study, and improved total-tract nutrient digestibility. The observed improvement of NDF degradation correlates with the increase in the molar proportion of acetate due to CAc treatment of barley under low $\mathrm{P}$ conditions, and may suggest an increased fibrolytic metabolic activity in the fermenter. These results also indicate that if $\mathrm{P}$ requirements of the rumen microbes are not met through readily available inorganic sources (diet or $\mathrm{P}$ recycled in saliva), rumen microbes may upregulate their endogenous phytase expression with CAc processing of barley. Another plausible reason may be that barley processing with $\mathrm{CAc}$ released $\mathrm{P}$ from $\mathrm{InsP}_{6}$ as recently shown for LAc-treated barley (Metzler-Zebeli et al., 2014). Because nearly $61 \%$ of barley P (Metzler- 
Zebeli et al., 2014) and $50 \%$ of soybean meal P (Viveros et al., 2000), which were the major $\mathrm{P}$ sources in our basal diet, is $\mathrm{InsP}_{6}$, we assume that almost $2 \mathrm{~g}$ from the total $3.1 \mathrm{~g}$ of $\mathrm{P} / \mathrm{kg}$ of $\mathrm{DM}$ of the native diet was $\mathrm{InsP}_{6}$.

From the target groups containing fibrolytic species and the investigated sentinel fiber degraders, the genus Prevotella appeared to have growth advantages with the CAc-treated barley in the low $\mathrm{P}$ diet. Because of the predominance of the genus Prevotella in the fermenter fluid, it may be feasible that Prevotella incorporated most of the $\mathrm{P}$ released from $\operatorname{InsP}_{6}$ by the acid treatment, which probably arose in parallel to an increased fibrolytic activity. Many rumen Prevotella species produce hemicellulases, endoglucanases, and pectinases and interact with cellulolytic microorganisms (Dehority, 1991; Miyazaki et al., 1997). Additionally, we can assume that, although far less abundant than the genus Prevotella, members of Clostridium cluster XIVa, which includes amylolytic as well as pectinolytic, hemicellulolytic, cellulolytic, and proteolytic species (Sleat and Mah, 1985; Cotta and Forster, 2006), and B. fibrisolvens were involved in the fiber degradation process, as these populations were also increased after CAc and LAc treatment of barley. Thus, CAc and LAc treatment enhanced soluble fiber degradation as reported previously (Harder et al., 2015a,b). Clostridium-cluster XIVa also includes butyrate-producing bacteria that thrive on resistant starch and soluble fibers ( $\mathrm{Li}$ et al., 2012), which might have contributed to the increased butyrate proportion after LAc treatment at low $\mathrm{P}$ conditions and a decreased acetate proportion, because they are known to convert acetate and lactate to butyrate (Duncan et al., 2004).

Anaerobic fungi may have slightly benefited from the low $\mathrm{P}$ diet either by having $\mathrm{P}$ requirements below that of bacteria or by filling the niche that opened up as other fibrolytic bacteria were depressed by the low $\mathrm{P}$ diet. Likewise, $M$. elsdenii may have benefited from an opening niche in the low $\mathrm{P}$ diet containing CON barley. As a lactate-utilizing bacterium (Hungate, 1966), M. elsdenii probably benefited from starch-degrading and lactate-producing bacteria. The potential $\mathrm{P}$ release from $\mathrm{InsP}_{6}$ due to the CAc and LAc treatment of barley in the low $\mathrm{P}$ diet may have attenuated this effect by changing the microbial community in favor of hemicellulolytic and cellulolytic bacteria, which may be in line with the improved NDF degradation with CAc treatment in low $\mathrm{P}$ diet.

Amylolytic bacteria and some hemicellulolytic species were previously shown to be less affected by low ruminal P concentration than cellulolytic bacteria (Durand and Komisarczuk, 1988). Our results for R. amylophilus may be seen in this context and might be related to a better utilization of organically bound $\mathrm{InsP}_{6}-\mathrm{P}$ when inorganic $\mathrm{P}$ was lacking. Microbial phytases dephosphorylate the organically bound $\mathrm{InsP}_{6}-\mathrm{P}$ to lower InsP forms and inorganic $\mathrm{P}$, which can be used by microbial cells for their metabolism (Field, 1981). In this context, Yanke et al. (1998) analyzed the phytase activity of several rumen bacterial strains, and found measurable phytase activities only in amylolytic bacteria. The higher sensitivity of cellulolytic bacteria compared with amylolytic bacteria may also be explained by their higher P requirements: $20 \mathrm{mg} / \mathrm{L}$ (Bryant et al., 1959) compared with that of amylolytic bacteria - up to 16 $\mathrm{mg} / \mathrm{L}$ (Caldwell et al., 1973).

A key finding of this study was the interaction between treatments with organic acids and dietary $\mathrm{P}$ levels concerning the concentration of total SCFA. The $\mathrm{CAc}$ and LAc treatments in combination with a low dietary $\mathrm{P}$ level enhanced the concentration of SCFA, but not under conditions of $\mathrm{P}$ supplementation. This enhancement of SCFA production under low P level corresponds well with the increased total bacterial gene copy numbers when barley was treated with LAc and CAc. This finding has important practical implications, particularly with respect to treatment effects of barley with CAc and LAc, which may have alleviated the lack of available $\mathrm{P}$ by stimulating both overall microbial abundance and their metabolic activity to utilize dietary $\mathrm{P}$ sources and produce SCFA. The reason for this might again be the improvement of degradation of $\operatorname{InsP}_{6}$ by acidic treatment of grains (Haraldsson et al., 2004; Metzler-Zebeli et al., 2014) and thus the increase in ruminal availability of $\mathrm{P}$ for ruminal bacteria. We also assume that the acid treatment might have improved the accessibility for ruminal microbes to the aleurone layer of barley and thereby to the storage location of InsP $_{6}$ (Reddy et al., 1982).

We observed an enhancement of propionate and decreased acetate:propionate ratio with acid treatments, and a decrease in the molar proportion of acetate and increase in butyrate, respectively, after LAc treatment. The potential of LAc treatment to enhance propionate formation has also been observed previously (Iqbal et al., 2009; Deckardt et al., 2015). It is possible that LAc treatment stimulated propionate formation by offering an electron sink for $\mathrm{H}_{2}$, leading to enhancement of the succinate-propionate pathway and the synthesis of propionate (Nisbet et al., 2009). On the other hand, although acetate is known as a main fermentation product of cellulolytic bacterial species (Christopherson et al., 2014), propionate and butyrate are produced by many bacterial groups using lactate, resistant starch, pectins, and hemicelluloses as substrates (Marounek and Dušková, 1999; Brouns et al., 2002; Duncan et al., 2004). Treatment with organic acid enhances the content of resistant starch and the recovery of soluble fibers 
(Harder et al., 2015a,b), which serve as substrates for the formation of propionate and butyrate (Marounek and Dušková, 1999; Brouns et al., 2002; Duncan et al., 2004).

We targeted only a limited number of microbial populations; therefore, it is hard to link the present abundances to the observed SCFA concentrations and other fermentation metabolites. Of the investigated bacterial taxa, members of the genus Prevotella and Clostridium cluster XIVa, M. elsdenii, and S. ruminantium may have directly or indirectly via cross-feeding contributed to the enhanced propionate formation with CAc and LAc treatment of barley (Strobel, 1992; Martin, 1998). Competition for nutrients among bacteria under a given $\mathrm{P}$ availability may have resulted in diverging effects of acid treatment in low and high $\mathrm{P}$ diets on microbial abundance and metabolic activity. With regard to the host animal, an increased molar propionate proportion due to the chemical treatment is highly beneficial, because propionate is a glucogenic precursor for the synthesis of glucose (Bergman, 1990), and can be regarded as the main source for gluconeogenesis in ruminants (Overton and Waldron, 2004).

We also observed a lower concentration of ammonia with CAc and LAc treatments, accompanied by a depression of CP degradation and the proportion of the branched-chain SCFA isovalerate. The decrease in isovalerate concentration after $\mathrm{CAc}$ and LAc treatments might indicate decreased deamination and proteolytic activity (Fraser et al., 2007). Isovalerate and isobutyrate are used by several rumen bacteria including cellulolytic bacteria. Therefore, modifications of their molar proportions might be linked to varying bacterial crossfeeding of these branched-chain fatty acids and changes in the microbial community (Allison et al., 1962; Bryant, 1973; Cummins and Papas, 1985). The study by Deckardt et al. (2015) showed similar effects after LAc treatment on barley grain. It is not clear whether LAc and $\mathrm{CAc}$ treatments provided protection of ruminal amino acid degradation, thus lowering ruminal $\mathrm{CP}$ degradation, or if the treatment with CAc and LAc lowered the amount of soluble protein of barley, resulting in a decreased ammonia concentration in the rumen fluid. It is also possible that the increase in fermentation intensity of fermentable carbohydrates by LAc and CAc treatments increased the energy availability for rumen microbes and promoted the incorporation of ammonia into microbial cells, leading to a decreased ammonia level in the ruminal fluid due to a greater use of ammonia for protein synthesis (Casper and Schingoethe, 1989; Cameron et al., 1991). This finding is supported not only by the observed changes in fermentation products of barley (Harder et al., 2015a,b) but also by the increased propionate level after CAc and
LAc treatments. Under in vivo conditions, the enhancement of microbial protein due to chemical treatment is beneficial to supply the host with metabolizable protein, particularly in high-producing cattle. Therefore, clarification of the effects of CAc and LAc treatment on protein metabolism is of high interest and will require further research.

In our study, protozoa and methanogens showed similar profiles, suggesting a certain dependency of methanogens on protozoa as $\mathrm{H}_{2}$ producer (Russell and Rychlik, 2001), making substrate available for methanogenesis. Data suggested that methanogenic archaeal genera responded differently to low and high $\mathrm{P}$ availability and acid treatment. Here, only the low-abundance Methanosphaera species was affected, whereas the dominating archaeal genus Methanobrevibacter was not modified. Accordingly, the interactive effect between acid treatment and $\mathrm{P}$ availability on Methanosphaera species might suggest that substrate availability and competition among microbes for $\mathrm{H}_{2}$ caused the differences in relative abundance of Methanosphaera species between treatments.

\section{CONCLUSIONS}

The processing of grain with CAc and LAc modulated the abundances of ruminal microbiota and fermentation profile, albeit differently with CAc and LAc treatment and dietary P level; CAc treatment increased the acetate proportion under low $\mathrm{P}$ supply, whereas LAc treatment increased propionate and butyrate proportions at both $\mathrm{P}$ levels and only low $\mathrm{P}$ supply, respectively. Both processing methods of barley reduced the degradation of $\mathrm{CP}$ and ammonia concentration compared with the control diet at both $\mathrm{P}$ levels. In conclusion, this Rusitec study suggests the potential for processing of grain with CAc and LAc to alleviate some negative effects of the deficiency of inorganic dietary $\mathrm{P}$ supply on the depression of ruminal total ruminal bacteria, selected bacterial species, and fiber degradation. Further research is warranted to determine the extent to which treatment with CAc and LAc can alleviate the shortage of inorganic $\mathrm{P}$ supplementation under in vivo conditions.

\section{ACKNOWLEDGMENTS}

We acknowledge the assistance with the trial and laboratory analyses of A. Dockner, M. Finsterböck, M. Wild, and S. Leiner (Institute of Animal Nutrition and Functional Compounds, University of Veterinary Medicine, Vienna). We are grateful to L. Schmid and P. Weinmann (HBLVA Rosensteingasse, Vienna, Austria) for their help with the Rusitec trial. This research 
was supported by the program "Sparkling Science" (project "Added value in nutrition") of the Austrian Federal Ministry of Science, Research and Economy (BMWFW), which we gratefully acknowledge.

\section{REFERENCES}

Allison, M. J., M. P. Bryant, and R. N. Doetsch. 1962. Studies on the metabolic function of branched-chain volatile fatty acids, growth factors for ruminococci. I. Incorporation of isovalerate into leucine. J. Bacteriol. 83:523-532.

Bergman, E. N. 1990. Energy contributions of volatile fatty acids from the gastrointestinal tract in various species. Physiol. Rev. 70:567-590.

Brask-Pedersen, D. N., L. V. Glitsø, L. Skov, P. Lund, and J. Sehested. 2013. Effect of exogenous phytase on degradation of inositol phosphate in dairy cows. J. Dairy Sci. 96:1691-1700.

Bravo, D., F. Meschy, C. Bogaert, and D. Sauvant. 2000. Ruminal phosphorus availability from several feedstuffs measured by the nylon bag technique. Reprod. Nutr. Dev. 40:149-162.

Brouns, F., B. Kettlitz, and E. Arrigoni. 2002. Resistant starch and "the butyrate revolution". Trends Food Sci. Technol. 13:251-261.

Bryant, M. P. 1973. Nutritional requirements of the predominant rumen cellulolytic bacteria. Fed. Proc. 32:1809-1813.

Bryant, M. P., I. Robinson, and H. Chu. 1959. Observations on the nutrition of Bacteroides succinogenes - a ruminal cellulolytic bacterium. J. Dairy Sci. 42:1831-1847.

Caldwell, D. R., M. Keeney, J. S. Barton, and J. F. Kelley. 1973. Sodium and other inorganic growth requirements of Bacteroides amylophilus. J. Bacteriol. 114:782-789.

Cameron, M. R., T. Klusmeyer, G. Lynch, J. Clark, and D. Nelson. 1991. Effects of urea and starch on rumen fermentation, nutrient passage to the duodenum, and performance of cows. J. Dairy Sci. 74:1321-1336.

Casper, D. P., and D. J. Schingoethe. 1989. Lactational response of dairy cows to diets varying in ruminal solubilities of carbohydrate and crude protein. J. Dairy Sci. 72:928-941.

Christopherson, M. R., J. Dawson, D. Stevenson, A. Cunningham, S. Bramhacharya, P. J. Weimer, C. Kendziorski, and G. Suen. 2014. Unique aspects of fiber degradation by the ruminal ethanologen Ruminococcus albus 7 revealed by physiological and transcriptomic analysis. BMC Genomics 15:1066.

Clark, W. D., J. Wohlt, R. Gilbreath, and P. Zajac. 1986. Phytate phosphorus intake and disappearance in the gastrointestinal tract of high producing dairy cows. J. Dairy Sci. 69:3151-3155.

Cotta, M., and R. Forster. 2006. The family Lachnospiraceae, including the genera Butyrivibrio, Lachnospira and Roseburia. Prokaryotes 4:1002-1021.

Cummins, K. A., and A. H. Papas. 1985. Effect of isocarbon-4 and isocarbon-5 volatile fatty acids on microbial protein synthesis and dry matter digestibility in vitro. J. Dairy Sci. 68:2588-2595.

Czerkawski, J. W., and G. Breckenridge. 1977. Design and development of a long-term rumen simulation technique (Rusitec). Br. J. Nutr. 38:371-384.

Deckardt, K., R. Khiaosa-ard, H. Grausgruber, and Q. Zebeli. 2014. Evaluation of various chemical and thermal feed processing methods for their potential to enhance resistant starch content in barley grain. Starke 66:558-565.

Deckardt, K., B. U. Metzler-Zebeli, and Q. Zebeli. 2015. Processing barley grain with lactic and tannic acid ameliorates rumen microbial fermentation and degradation of dietary fibre in vitro. J. Sci. Food Agric. http://dx.doi.org/10.1002/jsfa.7085.

Dehority, B. A. 1991. Effects of microbial synergism on fibre digestion in the rumen. Proc. Nutr. Soc. 50:149-159.

Duncan, S. H., P. Louis, and H. J. Flint. 2004. Lactate-utilizing bacteria, isolated from human feces, that produce butyrate as a major fermentation product. Appl. Environ. Microbiol. 70:5810-5817.

Durand, M., and R. Kawashima. 1980. Influence of minerals in rumen microbial digestion. Pages 375-408 in Digestive physiology and metabolism in ruminants. Y. Ruckebusch and P. Thivend, ed. MTP Press Ltd., Lancaster, UK.

Durand, M., and S. Komisarczuk. 1988. Influence of major minerals on rumen microbiota. J. Nutr. 118:249-260.

Federal Ministry of Health. 2004. Verordnung der Bundesministerin für Gesundheit und Frauen über die Mindestanforderungen für die Haltung von Pferden und Pferdeartigen, Schweinen, Rindern, Schafen, Ziegen, Schalenwild, Lamas, Kaninchen, Hausgeflügel, Straußen und Nutzfischen (1. Tierhaltungsverordnung) StF: BGBl. II Nr. 485/2004. Bundeskanzleramt Österreich, Vienna, Austria.

Feng, X., K. Knowlton, A. Dietrich, and S. Duncan. 2013. Effect of abomasal ferrous lactate infusion on phosphorus absorption in lactating dairy cows. J. Dairy Sci. 96:4586-4591.

Field, A. C. 1981. Some thoughts on dietary requirements of macroelements for ruminants. Proc. Nutr. Soc. 40:267-272.

Fonty, G., E. Forano, G. Gaudet, S. Komisarczuk, and P. Gouet. 1988. Données nouvells sur les bactéries cellulolytiques du rumen. Reprod. Nutr. Dev. 28(Suppl.1):19-32.

Fraser, G. R., A. Chaves, Y. Wang, T. McAllister, K. Beauchemin, and C. Benchaar. 2007. Assessment of the effects of cinnamon leaf oil on rumen microbial fermentation using two continuous culture systems. J. Dairy Sci. 90:2315-2328.

Haraldsson, A.-K., L. Rimsten, M. L. Alminger, R. Andersson, T. Andlid, P. Åman, and A.-S. Sandberg. 2004. Phytate content is reduced and $\beta$-glucanase activity suppressed in malted barley steeped with lactic acid at high temperature. J. Sci. Food Agric. 84:653-662.

Harder, H., A. Khol-Parisini, and Q. Zebeli. 2015a. Modulation of resistant starch and nutrient composition of barley grain using organic acids and thermal cycling treatments. Starke http://dx.doi. org/10.1002/star.201500040.

Harder, H., A. Khol-Parisini, and Q. Zebeli. 2015b. Treatments with organic acids and pullulanase differently affect resistant starch and fiber composition in flour of various barley genotypes (Hordeum vulgare L.). Starke 67:512-520.

Humer, E., and Q. Zebeli. 2015. Phytate in feed ingredients and potentials for improving the utilization of phosphorus in ruminant nutrition. Anim. Feed Sci. Technol. http://dx.doi.org/10.1016/j. anifeedsci.2015.07.028. In press.

Hungate, R. E. 1966. The Rumen and Its Microbes. Academic Press Inc., New York, NY.

Iqbal, S., Q. Zebeli, A. Mazzolari, G. Bertoni, S. Dunn, W. Yang, and B. Ametaj. 2009. Feeding barley grain steeped in lactic acid modulates rumen fermentation patterns and increases milk fat content in dairy cows. J. Dairy Sci. 92:6023-6032.

Jarrett, J. P., J. W. Wilson, P. P. Ray, and K. F. Knowlton. 2014. The effects of forage particle length and exogenous phytase inclusion on phosphorus digestion and absorption in lactating cows. J. Dairy Sci. 97:411-418

Kincaid, R., D. Garikipati, T. Nennich, and J. Harrison. 2005. Effect of grain source and exogenous phytase on phosphorus digestibility in dairy cows. J. Dairy Sci. 88:2893-2902.

Kincaid, R., and M. Rodehutscord. 2005. Phosphorus metabolism in the rumen. Pages 187-194 in Nitrogen and Phosphorus Nutrition of Cattle. Reducing the Environmental Impact of Cattle Operations. E. Pfeffer and A. N. Hristov, ed. CABI Publishing, Wallingford, UK.

Komisarczuk, S., M. Durand, P. Beaumatin, and G. Hannequart. 1987a. Effects of phosphorus deficiency on rumen microbial activity associated with the solid and liquid phases of a fermentor (Rusitec). Reprod. Nutr. Dev. 27:907-919.

Komisarczuk, S., G. Gaudet, G. Hannequart, G. Fonty, and M. Durand. 1988. Effects of a sub-deficiency in phosphorus on some aspects of cellulolytic activity of Bacteroides succinogenes. Reprod. Nutr. Dev. 28:79-80.

Komisarczuk, S., R. Merry, and A. McAllan. 1987b. Effect of different levels of phosphorus on rumen microbial fermentation and synthesis determined using a continuous culture technique. Br. J. Nutr. $57: 279-290$.

Konishi, C., T. Matsui, W. Park, H. Yano, and F. Yano. 1999. Heat treatment of soybean meal and rapeseed meal suppresses rumen 
degradation of phytate phosphorus in sheep. Anim. Feed Sci. Technol. 80:115-122.

Lengeler, J. W., G. Drews, and H. G. Schlegel. 1999. Biology of the Prokaryotes. Georg Thieme, Stuttgart.

Li, R. W., S. Wu, R. L. B. Vi, W. Li, and C. Li. 2012. Perturbation dynamics of the rumen microbiota in response to exogenous butyrate. PLoS ONE 7:e29392.

Marounek, M., and D. Dušková. 1999. Metabolism of pectin in rumen bacteria Butyrivibrio fibrisolvens and Prevotella ruminicola. Lett. Appl. Microbiol. 29:429-433.

Martin, S. A. 1998. Manipulation of ruminal fermentation with organic acids: a review. J. Anim. Sci. 76:3123-3132.

Matsui, H., K. Ogata, K. Tajima, M. Nakamura, T. Nagamine, R. I. Aminov, and Y. Benno. 2000. Phenotypic characterization of polysaccharidases produced by four Prevotella type strains. Curr. Microbiol. 41:45-49.

McDougall, E. I. 1948. Studies on ruminant saliva. I. The composition and output of sheep's saliva. Biochem. J. 43:99-109.

Metzler-Zebeli, B. U., K. Deckardt, M. Schollenberger, M. Rodehutscord, and Q. Zebeli. 2014. Lactic acid and thermal treatments trigger the hydrolysis of myo-inositol hexakisphosphate and modify the abundance of lower myo-inositol phosphates in barley (Hordeum vulgare L.). PLoS ONE 9: http://dx.doi.org/10.1371/ journal.pone.0101166.

Metzler-Zebeli, B. U., S. Schmitz-Esser, F. Klevenhusen, L. Podstatzky-Lichtenstein, M. Wagner, and Q. Zebeli. 2013. Grain-rich diets differently alter ruminal and colonic abundance of microbial populations and lipopolysaccharide in goats. Anaerobe 20:65-73.

Miyazaki, K., J. C. Martin, R. Marinsek-Logar, and H. J. Flint. 1997. Degradation and utilization of xylans by the rumen anaerobe Prevotella bryantii (formerly P. ruminicola ssp. brevis) B 14 . Anaerobe 3:373-381.

Mohammed, R., G. E. Brink, D. M. Stevenson, A. P. Neumann, K A. Beauchemin, G. Suen, and P. J. Weimer. 2014. Bacterial communities in the rumen of Holstein heifers differ when fed orchardgrass as pasture vs. hay. Front. Microbiol. 5:689. http://dx.doi. org/10.3389/fmicb.2014.00689.

Morse, D., H. Head, and C. Wilcox. 1992. Disappearance of phosphorus in phytate from concentrates in vitro and from rations fed to lactating dairy cows. J. Dairy Sci. 75:1979-1986.

Mullins, C. R., L. Mamedova, A. Carpenter, Y. Ying, M. Allen, I. Yoon, and B. Bradford. 2013. Analysis of rumen microbial populations in lactating dairy cattle fed diets varying in carbohydrate profiles and Saccharomyces cerevisiae fermentation product. J. Dairy Sci. 96:5872-5881.
Nisbet, D. J., T. R. Callaway, T. S. Edrington, R. C. Anderson, and N. Krueger. 2009. Effects of the dicarboxylic acids malate and fumarate on E. coli O157:H7 and Salmonella enterica typhimurium populations in pure culture and in mixed ruminal microorganism fermentations. Curr. Microbiol. 58:488-492.

NRC. 2001. Nutrient Requirements of Dairy Cattle. 7th rev. ed. Natl. Acad. Sci., Washington, DC.

Overton, T., and M. Waldron. 2004. Nutritional management of transition dairy cows: Strategies to optimize metabolic health. J. Dairy Sci. 87(E Suppl.):E105-E119.

Park, W., Y. T. Matsui, F. Yano, and H. Yano. 2000. Heat treatment of rapeseed meal increases phytate flow into the duodenum of sheep. Anim. Feed Sci. Technol. 88:31-37.

Preston, R. L., and W. Pfander. 1964. Phosphorus metabolism in lambs fed varying phosphorus intakes. J. Nutr. 83:369-378.

Reddy, N. R., S. Sathe, and D. Salunkhe. 1982. Phytates in legumes and cereals. Adv. Food Res. 28:1-92.

Russell, J. B., and J. L. Rychlik. 2001. Factors that alter rumen microbial ecology. Science 292:1119-1122.

Sleat, R., and R. Mah. 1985. Clostridium populeti sp. nov., a cellulolytic species from a woody-biomass digestor. Int. J. Syst. Bacteriol. 35:160-163.

Strobel, H. J. 1992. Vitamin $\mathrm{B}_{12}$-dependent propionate production by the ruminal bacterium Prevotella ruminicola 23. Appl. Environ. Microbiol. 58:2331-2333.

Van Soest, P. J., J. B. Robertson, and B. A. Lewis. 1991. Methods for dietary fiber, neutral detergent fiber, and nonstarch polysaccharides in relation to animal nutrition. J. Dairy Sci. 74:3583-3597.

VDLUFA. 2006. Handbuch der Landwirtschaftlichen Versuchs- und Untersuchungsmethodik (VDLUFA-Methodenbuch). Vol. III. Die chemische Untersuchung von Futtermitteln. VDLUFA-Verlag, Darmstadt, Germany.

Viveros, A., C. Centeno, A. Brenes, R. Canales, and A. Lozano. 2000. Phytase and acid phosphatase activities in plant feedstuffs. J. Agric. Food Chem. 48:4009-4013.

Wang, C., Q. Liu, J. Meng, W. Z. Yang, X. M. Yang, D. C. He, K. H Dong, and Y. X. Huang. 2009. Effects of citric acid supplementation on rumen fermentation, urinary excretion of purine derivatives and feed digestibility in steers. J. Sci. Food Agric. 89:2302-2307.

Yanke, L. J., H. D. Bae, L. B. Selinger, and K. J. Cheng. 1998. Phytase activity of anaerobic ruminal bacteria. Microbiology 144:15651573 